\title{
Extension of Lindow's Tables for Numerical Differentiation Using Newton-Stirling and Newton-Bessel Differences
}

\author{
By Herbert E. Salzer and Genevieve M. Kimbro
}

Lindow [1] gives several short tables of coefficients for obtaining the first and second derivative at intermediate points by differentiation of either the Newton-Stirling or Newton-Bessel interpolation formula [2]. The former involves central differences $\mu \delta_{0}{ }^{2 m+1}$ and $\delta_{0}{ }^{2 m}$ which are on the line with $f\left(x_{0}\right)$, and the latter involves central differences $\delta_{\frac{1}{2}}^{2 m+1}$ and $\mu \delta_{\frac{1}{2}}^{2 m}$ which are on the line with $f\left(x_{0}+\frac{h}{2}\right)$, $h$ being the tabular interval. Lindow's tables of Newton-Stirling coefficients are intended to interpolate for $f^{\prime}\left(x_{0}+p h\right)$ and $f^{\prime \prime}\left(x_{0}+p h\right)$ for either $0 \leq p \leq .25$ or for $.75 \leq p \leq 1.00$, in the latter case by choosing a new $x_{0}=$ original $x_{0}+h$ (and corresponding central differences opposite the next entry) and a new $p$ where now $-.25 \leq$ new $p \leq 0$. His tables of Newton-Bessel coefficients are intended to interpolate for $f^{\prime}\left(x_{0}+p h\right)$ and $f^{\prime \prime}\left(x_{0}+p h\right)$ for $.25 \leq p \leq .75$, or in the new variable $p_{1}$ given by $p=\frac{1}{2}+p_{1}$, for $-.25 \leq p_{1} \leq .25$. The reason for employing both Newton-Stirling and Newton-Bessel formulas (i.e. both tabular and mid-point central differences) is that by proper choice of $p$ or $p_{1}$ the argument is never more than one-fourth of a tabular interval away from the central differences employed, which should yield high accuracy.

The formulas for $f^{\prime}(x)$ and $f^{\prime \prime}(x)$ are of the form:

(1) $f^{\prime}\left(x_{0} \pm p h\right)=\frac{1}{h}\left\{\mu \delta_{0} \pm p \delta_{0}^{2}+\sum_{m=1}^{n}\left(A_{2 m+1}(p) \mu \delta_{0}^{2 m+1} \pm A_{2 m+2}(p) \delta_{0}^{2 m+2}\right)\right\}+R_{1, n}$

obtained by single differentiation of the Newton-Stirling interpolation formula, to be used for $\pm p$ ranging from -.25 to .25 .

$$
\begin{aligned}
f^{\prime}\left(x_{0}+\right. & p h) \equiv f^{\prime}\left(x_{0}+\frac{h}{2} \pm p_{1} h\right) \\
& =\frac{1}{h}\left\{\delta_{\frac{1}{3}} \pm p_{1} \mu \delta_{\frac{3}{3}}^{2}+\sum_{m=1}^{n}\left(B_{2 m+1}\left(p_{1}\right) \delta_{\frac{1}{2}}^{2 m+1} \pm B_{2 m+2}\left(p_{1}\right) \mu \delta_{\frac{1}{3}}^{2 m+2}\right)\right\}+R_{2, n}
\end{aligned}
$$

obtained by single differentiation of the Newton-Bessel interpolation formula, to be used for $p=\frac{1}{2} \pm p_{1}$ ranging from .25 to .75 , or $\pm p_{1}$ ranging from -.25 to .25 .

$$
\begin{aligned}
& f^{\prime \prime}\left(x_{0} \pm p h\right) \\
& \quad=\frac{1}{h^{2}}\left\{\delta_{0}^{2} \pm p \mu \delta_{0}^{3}+\sum_{m=1}^{n}\left(C_{2 m+2}(p) \delta_{0}^{2 m+2} \pm C_{2 m+3}(p) \mu \delta_{0}^{2 m+3}\right)\right\}+R_{3, n}
\end{aligned}
$$

obtained by double differentiation of the Newton-Stirling interpolation formula,

Received 29 August 1957. 
to be used for $\pm p$ ranging from -.25 to .25 .

$$
\begin{aligned}
& f^{\prime \prime}\left(x_{0}+p h\right) \equiv f^{\prime \prime}\left(x_{0}+\frac{h}{2} \pm p_{1} h\right) \\
& =\frac{1}{h^{2}}\left\{\mu \delta_{\frac{1}{3}}^{2} \pm p_{1} \delta_{\frac{3}{3}}^{3}+\sum_{m=1}^{n}\left(D_{2 m+2}\left(p_{1}\right) \mu \delta_{\frac{3}{3}}^{2 m+2} \pm D_{2 m+3}\left(p_{1}\right) \delta_{\frac{3}{3}}^{2 m+3}\right)\right\}+R_{4, n,}
\end{aligned}
$$

obtained by double differentiation of the Newton-Bessel interpolation formula, to be used for $p=\frac{1}{2} \pm p_{1}$ ranging from .25 to .75 , or $\pm p_{1}$ ranging from -.25 to .25 .

In the $n$th pair of terms only, the right hand term within the parentheses does not appear if the interpolation series (1), (2), (3), or (4) is not taken beyond $\mu \delta_{0}{ }^{2 n+1}, \delta_{\frac{1}{3}}^{2 n+1}, \delta_{0}{ }^{2 n+2}$ or $\mu \delta_{\frac{3}{3}}^{2 n+2}$ respectively. The formulas for the remainder terms $R_{i, n}, i=1,2,3$, or 4 depend also upon the parity of the order of the last difference retained in (1), (2), (3), or (4). To find $R_{i, n}$ explicitly one may differentiate the formulas for the remainder terms in the Newton-Stirling or Newton-Bessel formula ( $[3]$, p. 100, 102), making use of the properties of divided differences under repeated differentiation $([3]$, p. 66-67). For (1)-(4) there will be altogether eight different formulas for $R_{i, n}$, having either two, three, four or six terms, the use of which is quite troublesome and time-consuming, since each term involves the evaluation of a polynomial of higher degree and the estimation of a higher order derivative. For most practical problems one can almost always bypass the work in using the theoretically exact expression for $R_{i, n}$, by simply observing the last term retained in any of (1)-(4) in conjunction with the rate at which the terms are falling off in magnitude.

Following are the explicit expressions for the coefficients $A_{r}(p), B_{r}\left(p_{1}\right), C_{s}(p)$ and $D_{s}\left(p_{1}\right)$, as (even or odd) polynomials in $p$ or $p_{1}$, for $r=3(1) 10$ and $s=4(1) 10$ :

$$
\begin{aligned}
& A_{3}(p)=\frac{3 p^{2}-1}{6}, \quad A_{4}(p)=\frac{2 p^{3}-p}{12}, \quad A_{5}(p)=\frac{5 p^{4}-15 p^{2}+4}{120} \\
& A_{6}(p)=\frac{3 p^{5}-10 p^{3}+4 p}{360}, \quad A_{7}(p)=\frac{7 p^{6}-70 p^{4}+147 p^{2}-36}{5040} \\
& A_{8}(p)=\frac{2 p^{7}-21 p^{5}+49 p^{3}-18 p}{10080}, \\
& A_{9}(p)=\frac{9 p^{8}-210 p^{6}+1365 p^{4}-2460 p^{2}+576}{362880} \\
& A_{10}(p)=\frac{5 p^{9}-120 p^{7}+819 p^{5}-1640 p^{3}+576 p}{1814400} \\
& B_{3}\left(p_{1}\right)=\frac{12 p_{1}{ }^{2}-1}{24}, \quad B_{4}\left(p_{1}\right)=\frac{4 p_{1}{ }^{3}-5 p_{1}}{24} \\
& B_{5}\left(p_{1}\right)=\frac{80 p_{1}{ }^{4}-120 p_{1}{ }^{2}+9}{1920}, B_{6}\left(p_{1}\right)=\frac{48 p_{1}{ }^{5}-280 p_{1}{ }^{3}+259 p_{1}}{5760} \\
& B_{7}\left(p_{1}\right)=\frac{448 p_{1}{ }^{6}-2800 p_{1}{ }^{4}+3108 p_{1}{ }^{2}-225}{322560},
\end{aligned}
$$




$$
\begin{aligned}
& B_{8}\left(p_{1}\right)=\frac{64 p_{1}^{7}-1008 p_{1}{ }^{5}+3948 p_{1}^{3}-3229 p_{1}}{322560}, \\
& B_{9}\left(p_{1}\right)=\frac{2304 p_{1}{ }^{8}-37632 p_{1}{ }^{6}+157920 p_{1}{ }^{4}-154992 p_{1}{ }^{2}+11025}{92897280}, \\
& B_{10}\left(p_{1}\right)=\frac{1280 p_{1}^{9}-42240 p_{1}{ }^{7}+421344 p_{1}{ }^{5}-1382480 p_{1}{ }^{3}+1057221 p_{1}}{464486400} . \\
& C_{4}(p)=\frac{6 p^{2}-1}{12}, \quad C_{5}(p)=\frac{2 p^{3}-3 p}{12}, \\
& C_{6}(p)=\frac{15 p^{4}-30 p^{2}+4}{360}, \quad C_{7}(p)=\frac{3 p^{5}-20 p^{3}+21 p}{360}, \\
& C_{8}(p)=\frac{14 p^{6}-105 p^{4}+147 p^{2}-18}{10080}, \\
& C_{9}(p)=\frac{6 p^{7}-105 p^{5}+455 p^{3}-410 p}{30240}, \\
& C_{10}(p)=\frac{15 p^{8}-280 p^{6}+1365 p^{4}-1640 p^{2}+192}{604800} . \\
& D_{4}\left(p_{1}\right)=\frac{12 p_{1}^{2}-5}{24}, \quad D_{5}\left(p_{1}\right)=\frac{4 p_{1}^{3}-3 p_{1}}{24}, \\
& D_{6}\left(p_{1}\right)=\frac{240 p_{1}{ }^{4}-840 p_{1}{ }^{2}+259}{5760}, \quad D_{7}\left(p_{1}\right)=\frac{336 p_{1}{ }^{5}-1400 p_{1}{ }^{3}+777 p_{1}}{40320}, \\
& D_{8}\left(p_{1}\right)=\frac{448 p_{1}{ }^{6}-5040 p_{1}{ }^{4}+11844 p_{1}{ }^{2}-3229}{322560}, \\
& D_{9}\left(p_{1}\right)=\frac{576 p_{1}^{7}-7056 p_{1}{ }^{5}+19740 p_{1}{ }^{3}-9687 p_{1}}{2903040}, \\
& D_{10}\left(p_{1}\right)=\frac{11520 p_{1}{ }^{8}-295680 p_{1}{ }^{6}+2106720 p_{1}{ }^{4}-4147440 p_{1}{ }^{2}+1057221}{464486400} .
\end{aligned}
$$

The purpose of these present tables is to extend Lindow's tables which go only as far as the coefficients of the 6th differences in formulas (1)-(4) above, and give only $5 \mathrm{D}$ up to the 4 th difference coefficients and $4 \mathrm{D}$ for the 5 th and 6 th difference coefficients. These present tables give the coefficients $A_{r}(p), B_{r}\left(p_{1}\right)$, $C_{s}(p)$ and $D_{s}\left(p_{1}\right)$ at the same interval of .01 and the same range of $p$ or $p_{1}$ from 0 to .25, as occur in Lindow, but for every difference as far as the 10th difference inclusive, and to 10 significant figures. This represents a considerable extension of Lindow's original tables and should be useful in many calculations of the first and second derivatives at intermediate points, which arise in numerical differentiation work and in the solution of first or second order differential equations, where Lindow's tables are entirely inadequate. Anyone who has performed numerical differentiation, especially for the second derivative, is aware of the great loss in significant figures due to the power of $h$ in the denominator, as well as the subtraction of nearly equal terms in the numerator. For functions that are not deter- 
mined by either measurement, observation, experiment or approximation, but which are mathematically defined so as to be computable to any degree of precision, the only limitation to the accuracy in numerical differentiation is due to the truncating error in using a finite number of terms of the formulas (1)-(4) and the computing error due to the carrying of a fixed number of decimal places or significant figures in the computation. Thus Lindow's original tables severely limit the accuracy attainable for mathematically defined functions because of those two mentioned reasons. These present $10 \mathrm{~S}$ tables, as far as the 10th difference, are intended primarily to reduce considerably both truncation and computational errors.

The only other conveniently available tables for numerical differentiation at intermediate points, employing central-type differences, appear to be those of Davis [4] who gives, at intervals of .01, the Newton-Stirling and Newton-Bessel coefficients, but only as far as the 5 th difference and only to $5 \mathrm{D}$, and the Everett [2] coefficients as far as the 6 th central difference and to $10 \mathrm{D}$. However, all of Davis' coefficients are for the first derivative only. Davis' 10D Everett coefficients, giving 8-point accuracy, might suffice for most problems requiring just the first derivative. But Lindow must be extended anyhow to take care of the equally important second derivative, and thus we might as well be uniform in procedure and accuracy and use Lindow's arrangement for finding also the first derivative.

The present calculation was done originally using only a desk calculator, by exact computation of the numerators in the coefficients $A_{r}(p), B_{r}\left(p_{1}\right), C_{s}(p)$ and $D_{s}\left(p_{1}\right)$ in (1)-(4), and rounding only after division by the denominators. Thus all tabular entries should be correct to within a half-unit in the last (tenth) significant figure. All entries on the preliminary manuscript were rechecked by Norman Levine, employing the IBM 704, using double-precision (floating point) arithmetic. An additional differencing check was performed by hand upon the entries on the preliminary manuscript. Also a functional check was performed upon every entry in the typewritten final manuscript by computing the first and second derivatives of $(1+x)^{10}$ for $x=0(.01) .25$ and $x=.50(.01) .75$.

Convair-Astronautics

San Diego 12, California

1. M. Lindow, Numerische Infinitesimalrechnung, Berlin, Dümmler, 1928, p. 166-169.

2. E. T. WhitTAKER \& G. Robinson, Calculus of Observations, 4 th ed., Blackie \& Son, London, 1944 , p. $38-41$.

3. F. B. Hildebrand, Introduction to Numerical Analysis, McGraw-Hill, New York, 1956, p. $66-67,99-103$.

4. H. T. DAvis, Tables of the Higher Mathematical Functions, v. I, Principia Press, Bloomington, Ind., 1933, p. 140-147. 


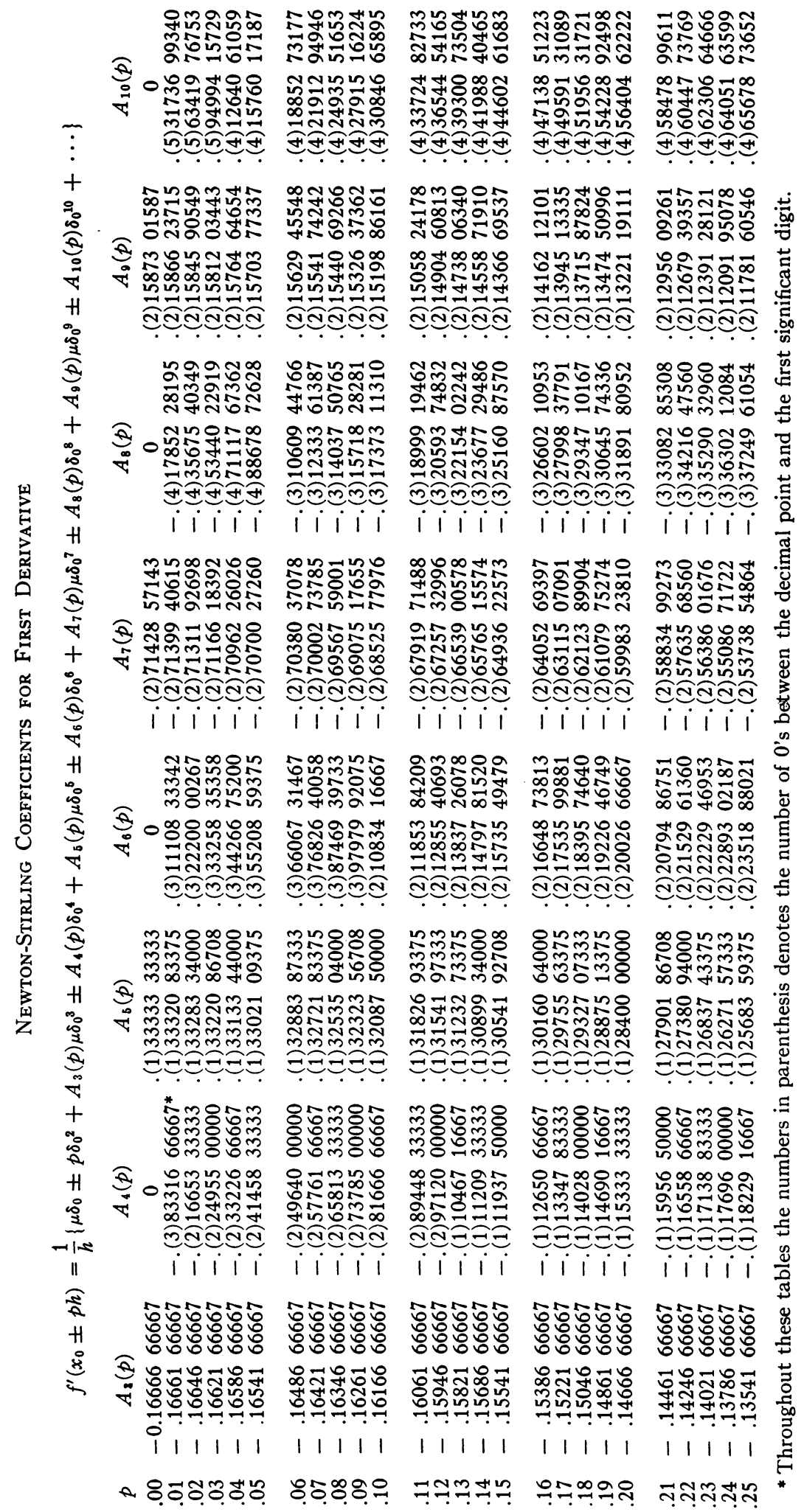




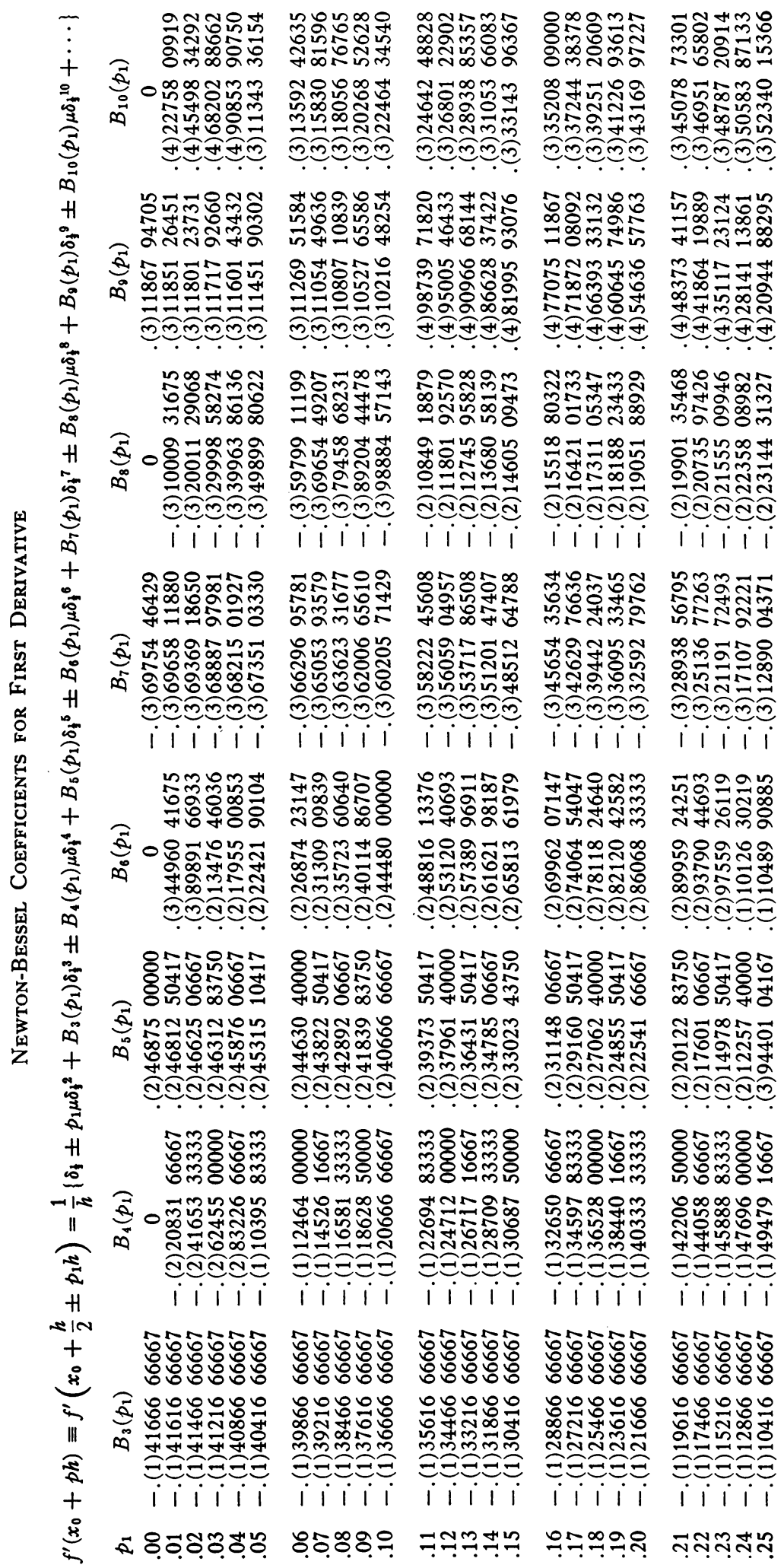



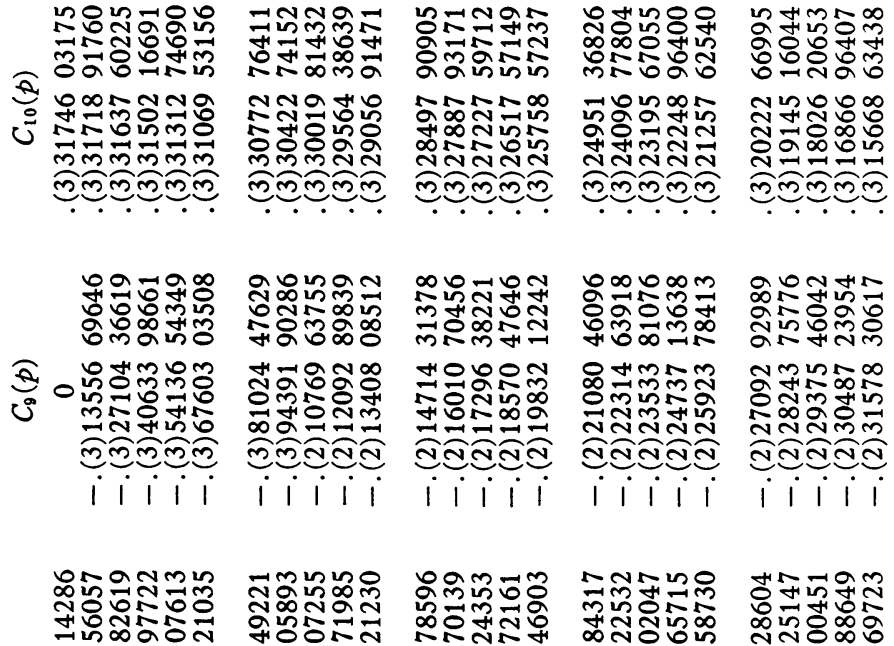

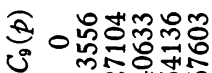

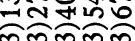
त्रक्तक्तल

iाiा

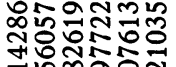

舟ํำํำ mํํ유ำ

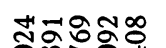

to유

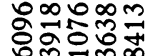

ลำษับี้ 무에

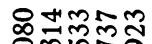

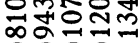

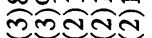

정스

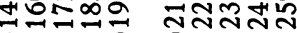

ลิธิธิธิธิธี

i i i

둗ำ

i i i i

సू누월유

준

오윰ำ

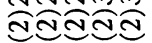

ii ii

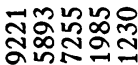

ํำผี 유츈전

츄ำ

눙푸워ำ

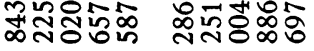

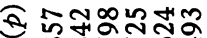

子OOกล

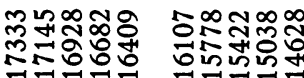

పีสิ₹तิ

즈는

ลีลิ즈응

ลิลีลสลส

मmलה

ลิธิธิธีลิ

취훙ㅇㅇㅇㅇㅠ

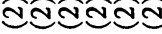

i i i i

i i i i

iाiंi

츰aㅁ

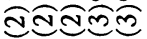

$+$

总

\section{DaN- 0}

유슈맄

ㅊำชัญส

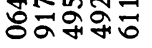

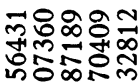

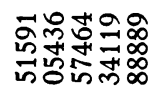

군대요

(

\&규ํำ

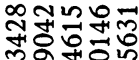

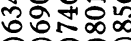

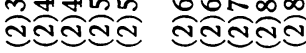

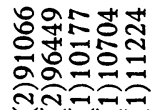

ㅇํㅇํำ

우아요

สํำกำ

ఏ气さささ

$+$

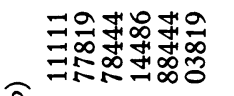

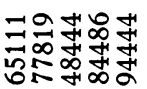

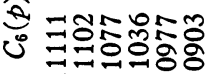

크크르을

चกำำ.

\%ㅇㅇㅇ웡으

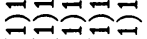

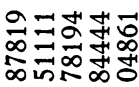

oñ

므중ำ

ㅊํำล

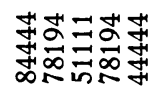

이요요

O유.

ลิลิวิธิธี

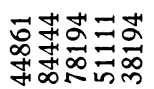

ㄷำลำ

종ㅇㅇㅇ

ลิิㅡ스으ำ

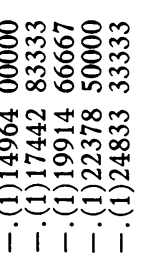

흉유.

춮ํำ

촟ำㅇำ

قิ气气气

i i i

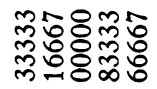

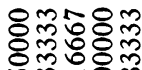

정유융

นสิ์ลัด

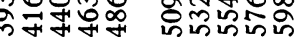

三气气

डิ $三 气$

iiii iiii

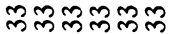

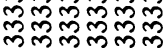

ఇెణణm

ल्लm्mలm

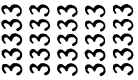

ఇణణmm

ఇెణmm

जलिल्लm

जिल्लm

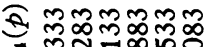

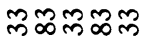

గొం

నం

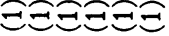

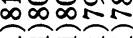

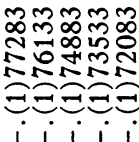

ఇనm

iิ $\rightarrow \infty$ in $\infty$

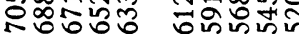

$==$

으응

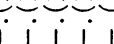

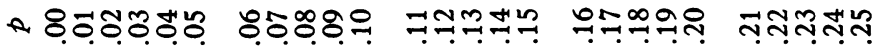




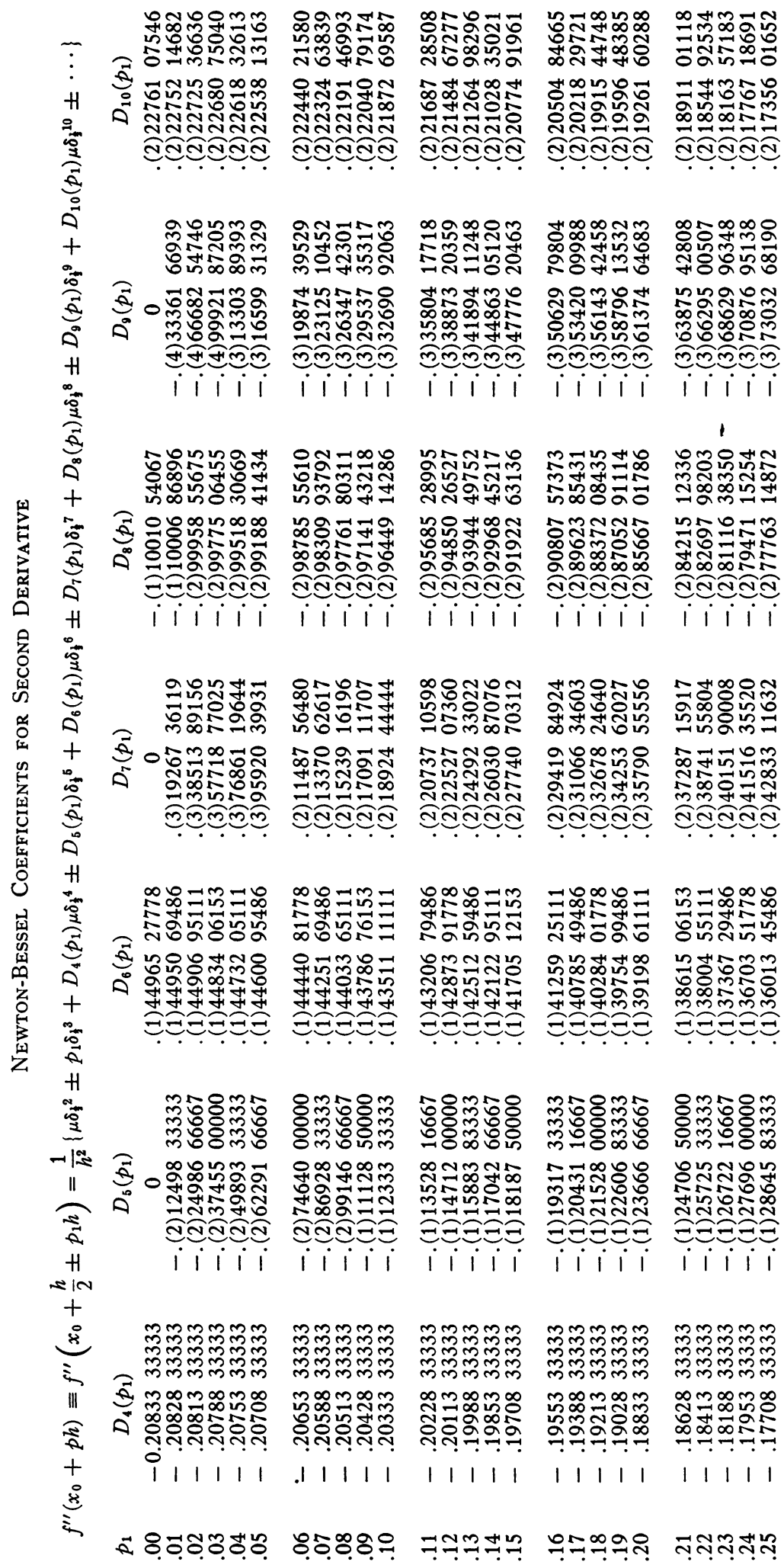

